\title{
Developing a Cell Culture System from Nile Tilapia (Oreochromis Niloticus, L.) Ovarian Tissue in Egypt
}

\author{
${ }^{1}$ Omaima Khamiss, ${ }^{2}$ Medhat. H. Hashem . \\ Animal Biotechnology Dept. \\ ${ }^{1,2}$ Genetic Engineering and Biotechnology Research Institute (GEBRI), Minufiya University.
}

\begin{abstract}
Cell culture from ovarian tissue of healthy female fingerlings Oreochromis niloticus was established with average weight of 20 to $30 \mathrm{gm} / f e m a l e$. Three culture media were screened and tested: Leibowitz L-15), Minimum essential medium (MEM) and RPMI 1640 medium. Cells were maintained at 16, 27 or $30^{\circ} \mathrm{C}$ for screening the favorable optimally incubation temperature. Culture medium was refreshed every 5 days. Among the three tested media, L-15 supplemented with $20 \%$ (FBS) supported higher cells attachment leading to cell proliferation than MEM and RPMI that didn't enhance the cell development and no cell proliferation was obtained with them. At different incubation temperature no proliferation were obtained when cells were incubated at $16^{\circ} \mathrm{C}$ compared with $27^{\circ} \mathrm{C}$ and $30^{\circ} \mathrm{C}$. This work is one of the rare reports of a cell culture system establishment in Egypt and unique from the ovarian tissue of O. niloticus. By using this technique, it should now be possible to develop different method of curing treatments and pathogens diagnosis because the fish can be bred in captivity and fingerlings reared under laboratory conditions.
\end{abstract}

I. Introduction:

More than 150 continuous cell lines have been established from fish. Most of them are either fibroblast-like or epithelial-like, and originate mainly from the tissues of salmonids or cyprinids (Fryer and Lannan, 1994). Fish cell lines have become an important tool for biomedical research (Hightower and Renfro, 1988) and more than 61 cell lines have been developed from teleost fishes (Wolf and Mann, 1980 and Sunil $\boldsymbol{e} t$ al., 2001). Fish cells have many practical advantages over mammalian cells: they can be incubated at room temperature $\left(20^{\circ} \mathrm{C}\right)$ and in the ambient atmosphere, which means that specialized incubators are not needed; and they can be stored for long periods at $4^{\circ} \mathrm{C}$, circumventing the need for freezing/thawing the cultures. Fish cells can be exposed to various aquatic environmental samples at varying osmolarities, something that has been done in mammals only with renal cells. Because of commonality of endpoints and because of simpler handling, fish cells could even replace the use of mammalian cells in some specific tests (for example, for the testing of nonsterile environmental matrices) (ECVAM, 2001). At present, established fish cell lines such as BB (bullhead brown trunk), GF (grunt blue stripped fin), FHM (fat head minnow skin), RTG-2 (rainbow trout gonads) and RTH-149 (rainbow trout hepatoma) are available commercially. But, for any genuine virus isolation, fish cell lines developed from the fish species concerned or related fish species are always advisable (Singh $\boldsymbol{e t}$ al., 1995 and Sunil et al., 2001). In that case, the researchers in the tropics are deprived of cell lines of their choice, and that may be the reason for the limited number of reports on viruses from warm water fishes compared with those from cold water ones (Chen et al., 1983 and Sunil et al., 2001).

Fish culture is an important industry where the production of fish worldwide increases every year. Intensification of fish adversely affects fish health and tends to produce poor environment for fish and increase their susceptibility to infections (Sakai, 1999). Disease outbreaks are encountered in the rapidly developing aquaculture industry and affecting the economic development of this sector (Yunxia et al., 2001 and Alexandra and Kim, 2006). Fish diseases especially with viral aetiology have become important, demanding effort in developing cell lines from the tropical cultivable fish species. In India for example, a cell line from caudal fin of rohu, Labeo rohita (Lakra and Bhonde, 1996), heart tissue of major carp (Rao et al., 1997), gill of mrigal Cirrhinus mrigala (Sathe et al., 1995), primary cell culture from kidney of Heteropneustus fossilis (Singh et al., 1995), and the primary cell culture system from the larvae of Poecilia reticulata (Kumar et al., 1998) are the only reports available.

The Nile tilapia, Oreochromis niloticus is widely used in tropical aquaculture and is becoming an increasingly popular species for culture in environmentally controlled conditions in temperate countries. The Nile tilapia is now the principal species of choice in freshwater aquaculture in many tropical countries (FAO 1995 and Mair, et al., 1997). It breeds in captivity and due to the same reason it becomes a good donor fish for various organs and tissues for cell line development. For any such work, availability of an appropriate medium and subculturing techniques are the limiting factors as these are specific to the type of tissue used and the type of cells developed irrespective of the fish species (Sunil $\boldsymbol{e t}$ al., 2001). The present work was aimed at developing a cell culture system from the ovarian tissue of $O$. niloticus. 


\section{Fish stock}

\section{Materials and methods:}

Healthy female fingerlings of O.niloticus with average 20 to $30 \mathrm{gm} /$ female were obtained from GEBRI rearing aquaria which were initiated from private farms in Sadat city, Minufiya Governorate. During stocking, the fingerlings were fed twice daily on food contains 25 to $30 \%$ protein approximately.

\section{Primary culture}

Ethanol-sterilized dissecting equipment was employed. All procedures were performed under sterile conditions in a laminar flow hood (EdgeGARD Hood, U.S.). All prepared buffers, solutions and media were sterilized by autoclaving or by filtration through $0.2 \mu \mathrm{m}$ syringe filter and all containers were sterilized by autoclaving (Sunil et al 2001 and Chris and Part 1997). Prior to Tissue sampling it were incubated at room temperature $\left(25-+2{ }^{\circ} \mathrm{C}\right)$ for $2 \mathrm{~h}$ in antibiotic incubation medium and after fish adaptation for tow weeks, the fish was kept for $15 \mathrm{~min}$ in well-aerated and sterilized water in order to flush loosely bound bacteria from fish skin. Fish was washed with autoclaved tap water at room temperature and swabbed with $70 \%$ ethanol. Fish was then decapitated and the ventral side of the body was cut opened aseptically. The ovarian tissues were obtained with sterile instruments and immersed in $70 \%$ ethanol for 5 seconds. The ovaries were rinsed for $15 \mathrm{~min}$ and thereafter twice for $5 \mathrm{~min}$ in $5 \mathrm{ml}$ medium containing $200 \mathrm{IU} / \mathrm{ml}$ penicillin, $200 \mu \mathrm{g} / \mathrm{ml}$ streptomycin and $400 \mu$ $\mathrm{g} / \mathrm{ml}$ gentamicin (Part et al., 1993 and Wood and Part, 1997). The ovaries were minced, then transferred to a sterilized glass mortar and grinded at room temperature. Cells were suspended in $12 \mathrm{ml}$ of culture medium of Leibowitz L-15 (MP Biomedicals, France), Minimum essential medium (MEM) (SIGMA, Germany) or RPMI 1640 (GIBCO, Scotland) medium. The three media were supplemented with $100 \mathrm{IU} / \mathrm{ml}$ penicillin, $100 \mu \mathrm{g} / \mathrm{ml}$ streptomycin, 200mg ml gentamycin and $20 \%$ heat-inactivated fetal bovine serum (FBS). The $\mathrm{pH}$ of the complete medium including FBS and antibiotics was 7.5-7.7. Cells were seeded into $25 \mathrm{~cm}^{2}$ tissue culture flask ( $\mathrm{T}$ flasks). Three trails of primary cell cultures were initially maintained and incubated at three different temperatures 16,27 or $30^{\circ} \mathrm{C}$ for screening the favorable incubation temperature. When monolayer was confluent, cells were sub-cultivated at a ratio of 1:2 every $5 \mathrm{~d}$ and the concentration of FBS was reduced to $10 \%$.

Leibowitz L-15 medium is designed for use in $\mathrm{CO}_{2}$-free systems and it contains no nominal $\mathrm{HCO}_{3}{ }^{-}$. It is buffered by its complement of salts (phosphates) (Qin et al., 2005).

Growth curve: Growth characteristics of the newly established cell lines were evaluated at selected temperatures, as well as with various media. To determine the incubation temperature for optimal cell growth, $1-2 \times 10^{5}$ cells at the 12 th or later passage were seeded in $3.5 \mathrm{~cm}$ tissue culture flasks (Curning Labware, Coming, NY), and cells were incubated at 16,27 or $30^{\circ} \mathrm{C}$. On alternate days for a total of $14 \mathrm{~d}$, cells from two or three flasks at each temperature, when the flasks were covered by a monolayer of cells, the cells were trypsinized (PBS, $0.05 \%$ trypsin, $0.03 \%$ EDTA) for $10 \mathrm{~min}$ and counted with a hemocytometer; average cell counts were calculated. In the same manner, the effects of different tissue culture media (RPMI, L15 and minimum essential medium) on cell growth was as-sassed. Regular, daily microscopic observation was carried out to follow up the cell development. Cell viability was always confirmed by trypan blue staining. Cells were counted by using hemocytometer $48 \mathrm{hrs}$ post seeding and then $3,5,7,9,11$ and 12 days.

\section{Results}

Among the three media tested, Leibovitz-15 (L-15), when supplemented with $20 \%$ foetal bovine serum (FBS) supported higher percentage attachment of cells leading to cell proliferation than minimum essential medium (MEM) and RBMI that no results were obtained with them. Ovaries cells which were grown in L-15 medium supplemented by $20 \% \mathrm{FBS}$, and incubated at $25^{\circ} \mathrm{C}$. After the flasks were covered by cells monolayer the cells were trypsinized (PBS, $0.05 \%$ trypsin, $0.03 \%$ EDTA) for $10 \mathrm{~min}$., counted and diluted to $1 \mathrm{x} 10^{5}$ cells $/ \mathrm{ml}$. Then cells which were seeded in $3.5 \mathrm{~cm}$ diameter cell culture plates in rate of $1 \mathrm{ml}$ of cells per each plate were seeded into $25 \mathrm{~cm}^{2}$ tissue culture flasks and incubated at 16, 27 or $30 \mathrm{C}^{\circ}$. Following the first passage, cells derived from the same tissue/organ were pooled and sub-cultured. Initial growth of Nile tilapia (Oreochromis niloticus, L.) ovarian cell culture was observed 2 to $3 \mathrm{~d}$ following seeding of minced tissue explants or dissociated cells. Cell colonies of various sizes formed within $7 \mathrm{~d}$, and confluent cell monolayer were achieved by days 9 to 12 . By contrast, no results were obtained when cells were incubated at $16 \mathrm{C}^{\circ}$ compared with 27 and $30 \mathrm{C}^{\circ}$. When the culture medium was changed after five days, the unattached cells were washed away and ovaries tissue cells were attached to flask and began to elongate. During the following days, cells grow by division and spreading, to form monolayer approximately 7 to 10 days after seeding (fig.1). Results indicated that cells pass through four different phases. The first phase is lag phase (from 0 to $2^{\text {nd }}$ day) in which there is a small increase in cells number. The second phase is $\log$ phase (from $2^{\text {nd }}$ to $7^{\text {th }}$ day) where the cells increase exponentially. The stationary phase started from the ninth day where cells showed constant in number and began to decrease at the decline phase. 


\begin{tabular}{|c|c|}
\hline \multicolumn{2}{|c|}{ Characteristics of Nile tilapia (Oreochromis niloticus, L.) ovarian cell line } \\
\hline $\begin{array}{ll}\text { Optimum growth medium } & \text { Optimum growth } \\
\text { temperature } & \\
\text { FBS requirement } & \\
\text { Doubling time } & \\
\text { Morphology } & \end{array}$ & $\begin{array}{l}\text { Leibowitz L-15 } \\
25^{\circ} \mathrm{C} \\
10 \% \\
30-36 \mathrm{hr} \\
\text { Epithelial/fibroblastic }\end{array}$ \\
\hline
\end{tabular}

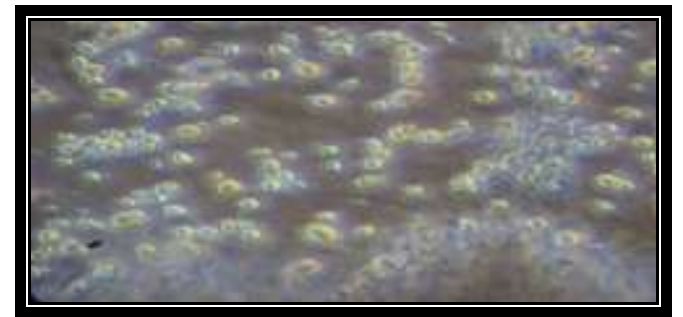

(a)

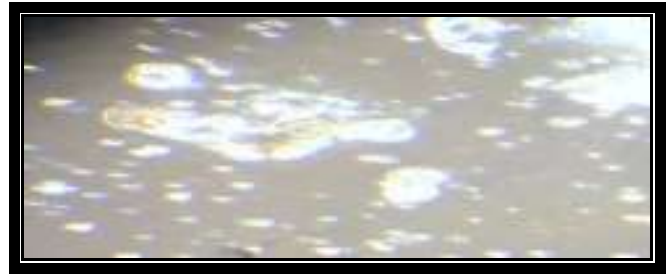

(c)

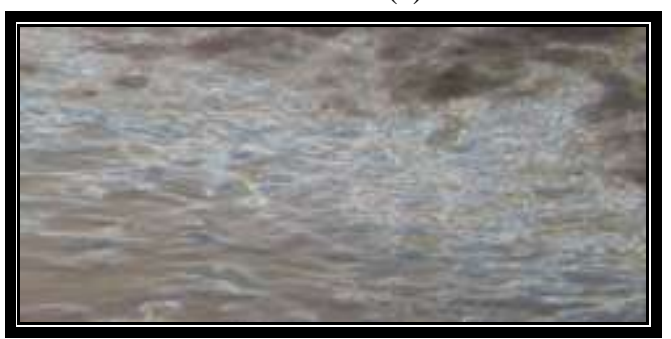

(e)

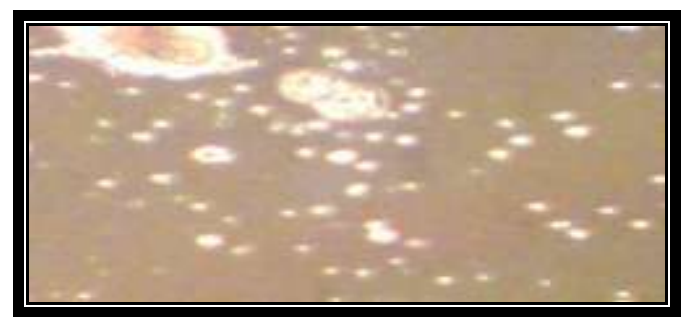

(b)

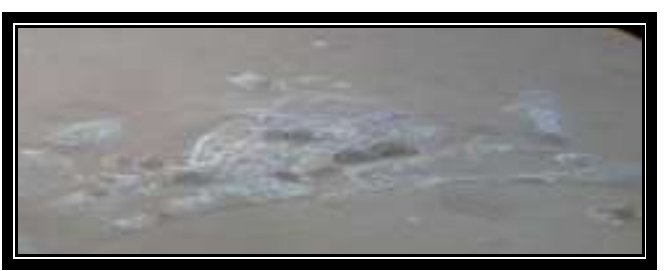

(d)

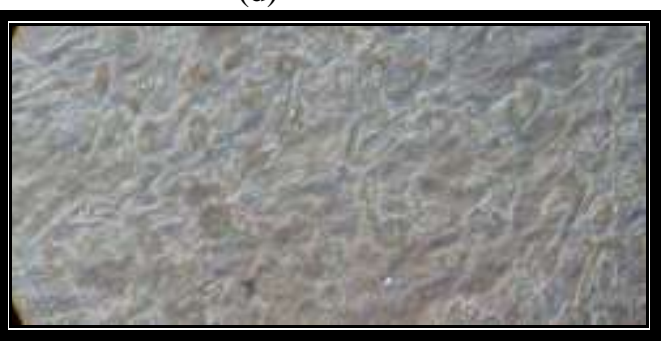

(f)

Fig. 1: Illustrates different stages of $O$. niloticus fish ovary cell culture. a., cells of ovarian tissue immediately after seeding, $\mathrm{b}$ and c. cell proliferation, d. attachment and elongation of cells, e. monolayer formation and $\mathrm{f}$.

Cells in the second passage.

\section{Discussion}

Mechanical procedure (grinding) was used in this study for obtaining separated cells without trypsin treatment. Thus because Trypsin phosphate versene glucose (TPVG) at the concentration of $0.2 \% \mathrm{w} / \mathrm{v}$ was found to be toxic to the primary cell culture system developed by Sunil $\boldsymbol{e t}$ al. $\mathbf{2 0 0 1}$ while diluting TPVG to a final concentration of $0.025 \%$ trypsin, enhanced the survival and attachment potential of extracted cells. As for testing three media for establishing the cell culture system as stated previously in the results, the minimum essential medium MEM., RBMI and L-15, each was supplemented with $20 \%$ foetal bovine serum, it was clear that L-15 was found to be the most suitable medium in terms of its efficacy to support rapid cells attachment and cell proliferation. Suitability of L-15 in supporting fish cell lines growth compared to that of other media has been documented by Fernandez et al. (1993), when they compared the growth responses of 28 fish cell lines in different media at various temperatures and sodium chloride concentrations.

In this study no tissue derived growth factors were added. The ovarian tissue of $C$. gariepinus in the study of Sunil $\boldsymbol{e t}$ al. (2001) was found to require tissue derived growth factors present in fish muscle extract, ovary extract and prawn haemolymph, for attachment and proliferation. Similar observations also, were registered by Kumar et al. (1998) when they studied the development of a primary cell culture system from the embryonic tissue of Poecilia. reticulata. In contrast primary cultures of epithelial cells from rainbow trout gills were not found to respond to any of the growth factors employed Part $\boldsymbol{e t}$ al., 1993. This precisely indicates that there is no fixed rule as far as growth factors are concerned and the required growth factors have to be investigated for every fish species studied, and even for every organ used for the cell culture development (Sunil et al 2001). Certain minimal requirements, depending on cell type, must be satisfied before cells multiply in culture, in this study $20 \%$ FBS was used in primary culture and this reduced to $10 \%$ in subculture media. 
Similar concentrations were used by Qin et al (2005) who developed a new tropical marine fish cell line from grouper susceptible to irridovirus and nodavirus. Sunil et al. (2001) used 10\% FBS with ovarian tissue cell culture of African catfish Clarias gariepinus and 5\% FBS was used by Part et al. (1993) who obtained primary cultures of epithelial cells from rainbow trout gills. Referenced to (Ham and McKeehan, 1978 and 1979; Ham, 1981 and 1984) serum helps to support cell growth in a wide variety of different ways, all of which must be replaced or compensated for in order to obtain growth in a defined medium. Cell cultures maintained in basal nutrient culture media supplemented with bovine, fetal bovine or calf serum are well established conventional models. Although modern basal nutrient medium formulations allow the serum in the range of $5 \%$ to $20 \%$ to be used as a supplement, this biological fluid still represents a significant contribution of undefined components to the culture medium (ECVAM, 2001). However, the presence of mammalian serum may influence the physiology of the fish cells (Tocher and Dick, 1990) and their toxicological responses (Behrens et al., 2001).

In vitro propagation of selected Nile tilapia (Oreochromis niloticus, L.) ovarian cell line indicated that growth was maximal at $25^{\circ} \mathrm{C}$, in $\mathrm{L} 15$ medium which was the temperature selected for the establishment of these fish cell lines. It should be noted that this optimal growth temperature was not due to the initial adaptation of Nile tilapia cells cultivated at $25^{\circ} \mathrm{C}$ since the initial growth of Nile tilapia cells progressed much slower when an alternative temperature $\left(16^{\circ} \mathrm{C}, 27^{\circ} \mathrm{C}\right.$ and $\left.30^{\circ} \mathrm{C}\right)$ was selected. Wolf (1979) suggested culturing fish cells at temperatures slightly above that preferred by the intact animal, and cell lines established from other coldblooded marine animals similarly show a differential temperature optimum for the host (Lannan 1984, Middlebrooks 1979 and 1980).

At different incubation temperature $\left(16^{\circ} \mathrm{C}, 27^{\circ} \mathrm{C}\right.$ and $\left.30^{\circ} \mathrm{C}\right)$ in this study, no results were obtained when cells were incubated at $16^{\circ} \mathrm{C}$ compared with $27^{\circ} \mathrm{C}$ and $30^{\circ} \mathrm{C}$. Kennedy et al. (1991) and Pawlowski et al. (2000) results indicated that, incubation temperature

is an experimental variable in fish cell culture. Primary cell iotic metabolism or endocrine-mediated responses. With respect to fish cell lines, growth and cellular functions are strongly temperature dependent (Pawlowski et al., 2000). As a consequence, temperature affects the cyto-toxic responses of fish cells (Castaño et al., 1989).

In conclusion, a growth medium in this work for the development and maintenance of a cell culture system from the ovarian tissue of $O$. niloticus has been achieved. Moreover, for it's sub-culturing, serum concentration was reduced to $10 \%$. More work has to be carried out on this field of in vitro cell culture system of $O$. niloticus tissue. This work is one of the rare reports of a cell culture system establishment in Egypt and unique from the ovarian tissue of $O$. niloticus. By using this technique, it should now be possible to develop primary cell cultures, to have cell line and develop the different method of curing treatments and diagnosis because the fish can be bred in captivity and fingerlings raised under laboratory conditions.

\section{References}

Alexandra, A. and T. D. Kim 2006. Biotechnology offers revolution to fish health management. Trends in Biotechnology. 24 (5), 201-205 among cultured freshwater fish (Oreochromis miolicus) in relation to the incidence of bacterial pathogens at Ismailia Governorate. J. Egypt. Med. Ass., 51(4): 837-847.

[2] Behrens, A., K. Schirmer, N.C. Bols, and H. Segner 2001. Polycyclic aromatic hydrocarbons as inducers of cytochrome P4501A enzyme activity in the rainbow trout liver cell line, RTL-W1, and in primary cultures of rainbow trout hepatocytes. Environmental Toxicology and Chemistry 20:632-643.

[3] Castaño, A., J.V. Tarazona, A. Santamaría, and F. Sanz, 1989. Utilización de células de peces en los ensayos alternativos de ecotoxicologiá acu tica. Revista de Toxicología 6:150.

[4] Chen, S.N., Chi, S.C. and G.H. Kou 1983. A cell line derived from Tilapia ovary. Fish Pathol. 18 1:. 13-18.

[5] Chris, M. w. and P. part 1997. Cultured branchial epithelia from freshwater fish gills. J. Exp. Bio., 200: 1047-1059.

[6] ECVAM (European Centre for the Validation of Alternative Methods) 2001. The Use of Fish Cells in Ecotoxicology.The Report and Recommendations of ECVAM Workshop Italy, on 22-24 October 2001.

[7] FAO. 1995. Aquaculture Production Statistics 1984-1993. FAO Fish. Circ. 815 Rev. 7. 186n p

[8] Fernandez, R.D., M. Yoshimizu, Y. Ezura, T. Kimura, 1993. Comparative growth response of fish cell lines in different media, temperatures, and sodium chloride concentrations. Fish Pathol. 28: 27-34.

[9] Fryer, J.L. and C.N. Lannon 1994. Three decades of fish cell culture: a current listing of cell lines derived from fish. J. Tiss. Cult. Methods 16: 87-94.

[10] Ham, R.G. 1981. Survival and growth requirements of nontransformed cells. Handbook of Experimental Pharmacology 57: 13-88.

[11] Ham, R.G. 1984. Selective media. Cell Separation: Methods and Selected Applications Vol. 3 (eds. Pretlow, T.G., II and Pretlow, T.P.) pp. 209-236. Academic Press, New York.

[12] Ham, R.G. and W.L. McKeehan 1978. Nutritional requirements for clonal growth of nontransformed cells. Nutritional Requirements of Cultured Cells (ed. Katsuta, H.) pp. 63-115. Japan Scientific Societies Press, Tokyo.

[13] Ham, R.G. and W.L. McKeehan 1979. Media and growth requirements. Methods of Enzymolology 58: 44-93.

[14] Hightower, L.E. and L.J. Renfro 1988. Recent applications of fish cell culture to biomedical research. J. Exp. Zool. 248, pp. 290302

[15] Kennedy, C.J., K.A. Gill, and P.J. Walsh 1991. Temperature acclimation of xenobiotic metabolizing enzymes in cultured hepatocytes and whole liver of the Gulf toadfish, Opsanus beta. Canadian Journal of Fisheries and Aquatic Science 48: 1212-1219.

[16] Kumar G.S., I.B.S. Singh and R. Philip 2001.Development of a cell culture system from the ovarian tissue of African catfish (Clarias gariepinus), Aquaculture 194: 1-62. 
[17] Kumar, G.S., I.S.B. Singh, P. Rosamma, M. Raveendranath, and J .Shanmugam 1998. Efficacy of fish and prawn muscle extracts as supplements to development of a primary cell culture system from larval tissue of aquarium fish Poecilia reticulata. Indian J. Exp. Biol. 36: 91-94.

[18] Lakra, W.S. and R.R. Bhonde, 1996. Development of primary cell culture from the caudal fin of an Indian Major carp, Labeo rohita (Ham.). Asian Fish. Sci. 9: 149-152.

[19] Lannan, C. N.; Winton, J. R.; Fryer, J. L. Fish cell lines: establishment and characterization of nine cell lines from salmonids. In Vitro Cell. Dev. Biol. 20:671 i76; 1984.

[20] Mair, G.C., J.S., Abucay, D.O.F., Skibinski, T.A., Abella, and J.A. Beardmore 1997. Genetic manipulation of sex ratio for the large scale production of all-male tilapia Oreochromis niloticus L. Canadian Journal of Fisheries and Aquatic Sciences, 54(2): 396-404.

[21] Middlebrooks, B. L.; Ellender, R. D.; Wharton, J. H. (1979): Fish cell cultures a new cell line from Cynoscion nebulosus. In Vitro Cell. Dev. Biol. 15:109-111;

[22] Middlebrooks, B. L.; Mak, P. C.; Ellender, R. D.( 1980): Properties of an established cell line from the Atlantic croaker (Micropogon undulatus). Proc. Soc. Exp. Biol. Med. 165:123-128.

[23] Part, P., L. Morrghan, E. Bergstrom, and P. Sjoberg, 1993. Primary cultures of epithelial cells from rainbow trout gills. Indian J. Exp. Biol. 175: 219-233

[24] Pawlowski, S., M. Islinger, A. Völkl, and T. Braunbeck, 2000. Temperature-dependent vitellogenin-mRNA expression in primary cultures of rainbow trout (Oncorhynchus mykiss) hepatocytes

[25] Qin Q. W. T. H. Wu, T. L. Jia, A. Hegde and R. Q. Zhang 2005. development and characterization of a new tropical marine fish cell line from grouper susceptible to irridovirus and nodavirus. J. Viro. Meth., 131: 58-64.

[26] Rao, K.S., Joseph, M.A., Shanker, K.M. and C.V Mohan 1997. Primary cell culture from explants of heart tissue of Indian Major carps. Curr. Sci. 73: 4-375.

[27] Sakai, M. 1999. Current research status of fish immunostimulants. Aquaculture. 172: 63-92.

[28] Sathe, P.S., D.T. Muraya, A. Basu, S.S. Gogate. and K. Banerjee 1995. Establishment and characterization of a new fish cell line, MG-3, from gills of Mrigal, Cirrhinus mrigala. Indian J. Exp. Biol. 33: 589-594.

[29] Singh, I.S.B., Rosamma, P., Raveendranath, M. and J. Shanmugam, 1995. Development of primary cell cultures from kidney of fresh water fish Heteropneustus fossilis. Indian J. Exp. Biol. 33: 95-599.

[30] Sunil G. K, I. S. Bright Singh and R. Philip2001. Development of a cell culture system from the ovarian tissue of African catfish (Clarias gariepinus). Aquaculture, 194 (1-2): 51-62

[31] Tocher, D.R. and J.R. Dick 1990. Polyunsaturated fatty acids metabolism in cultured fish cells: incorporation and metabolism of (n-3) and (n-6) series by Atlantic salmon (Salmo salar) cells. Fish Physiology and Biochemistry 8: 311-319.

[32] Wolf, K. and J.A. Mann 1980. Poikilotherm vertebrate cell lines and viruses: a current listing for fishes. In Vitro Cell. Dev. Biol. 16: $168-169$.

[33] Wolf, K. 1979 Cold-blooded vertebrate cell and tissue culture Methods in enzymology LVIII:466-477; .

[34] Wood, C. M. and P. Part 1997. Cultured branchial epithelia as a model for the fish gill. Journal of Experimental Biology 200: 1047-1059.

[35] Yunxia, Q., S. Jianzhong and W. Guoliang 2001. A review of principal bacterial diseases of mariculture fish. Transactions of Oceanology and Limnology. 2: 78-87. 